Artikel Penelitian

\title{
Pengaruh Pemberian Kopi terhadap Kadar Kolesterol dan Trigliserida pada Tikus Wistar (Rattus novergiccus)
}

\author{
Millah Fithriyah Zindany ${ }^{1}$, Husnil Kadri ${ }^{2}$, Almurdi $^{3}$
}

\begin{abstract}
Abstrak
Kebiasaan mengonsumsi kopi banyak dikaitkan dengan kelainan pada kesehatan dan berbagai macam penyakit. Kopi mengandung lebih dari seribu molekul zat yang berbeda diantaranya kafein, kafestol, kahweol, dan asam klorogenik sering dihubungkan dengan metabolisme lipid. Tujuan penelitian ini adalah untuk mengetahui pengaruh pemberian kopi terhadap kadar kolesterol dan trigliserida pada tikus galur Wistar (Rattus novergiccus). Jenis penelitian ini adalah eksperimental dengan rancangan post test only control group design. Sampel penelitian ini adalah 24 ekor tikus putih jantan (Rattus novergiccus) yang dibagi menjadi 4 kelompok yaitu kelompok kontrol (K), perlakuan 1 (DR), perlakuan 2 (DS), dan perlakuan 3 (DT). K hanya diberi diet standar tanpa kopi, DR diberikan diet kopi dosis rendah setara 3 cangkir kopi $(0,39 \mathrm{mg} / 3 \mathrm{ml})$, DS diberikan diet kopi dosis sedang setara 6 cangkir kopi $(0,78 \mathrm{mg} / 3 \mathrm{ml})$, DT diberikan diet kopi dosis tinggi setara 10 cangkir kopi $(1,3 \mathrm{mg} / 3 \mathrm{ml})$ selama 4 minggu (28 hari). Pengukuran kadar kolesterol dan trigliserida menggunakan spektofotometer.Hasil penelitian didapatkan rerata kadar kolesterol $\mathrm{K}$ $(35,80 \pm 10,84 \mathrm{mg} / \mathrm{dl})$, DR $(56,60 \pm 7,66 \mathrm{mg} / \mathrm{dl})$, DS $(60,60 \pm 12,13 \mathrm{mg} / \mathrm{dl})$, DT $(73,00 \pm 16,39 \mathrm{mg} / \mathrm{dl})$ dan rerata kadar trigliserida K $(97,00 \pm 6,44 \mathrm{mg} / \mathrm{dl})$, DR $(27,80 \pm 11,90 \mathrm{mg} / \mathrm{dl})$, DS $(29,20 \pm 16,02 \mathrm{mg} / \mathrm{dl}), \mathrm{DT}(36,00 \pm 15,08 \mathrm{mg} / \mathrm{dl})$. Uji analisis one-way ANOVA dan Post-hoc menunjukkan perbedaan yang bermakna pada kadar kolesterol total dan trigliserida kelompok perlakuan dengan kelompok kontrol $(p<0,05)$ namun tidak terdapat perbedaan bermakna antar kelompok perlakuan $(p>0,05)$. Simpulan penelitian ini adalah terdapat perbedaan bermakna kadar kolesterol total dan trigliserida antara kelompok perlakuan dengan kelompok kontrol tetapi perbedaan dosis tidak memberikan perbedaan bermakna.
\end{abstract}

Kata kunci: kopi, kafein, kolesterol, trigliserida

\begin{abstract}
Coffee has composition of over thousand substances namely caffeine, cafestol, kahweol, and chlorogenic acid which are correlated with lipid metabolism. The objective of this study was to determine effect of coffee on cholesterol and triglyceride of Wistar strain of rats (Rattus novergiccus). This was an experimental with posttest only control group design. Samples were 24 male white rats strain Wistar divided into 4 groups: control (K), treatment 1 (DR), treatment 2 $(D S)$, and treatment $3(D T)$. $K$ was not treat with coffee, DR were given low dose of coffee equivalent to 3 cups (0.39 $\mathrm{mg} / 3 \mathrm{ml})$, DS were given moderate dose of coffee equivalent to 6 cups $(0.78 \mathrm{mg} / 3 \mathrm{ml}), D T$ were given high dose of coffee equivalent to 10 cups $(1.3 \mathrm{mg} / 3 \mathrm{ml})$ for 4 weeks (28 days). Cholesterol and triglyceride then measured with sphectophotometer. The result showed the mean of total cholesterol levels $K(35.80 \pm 10.84 \mathrm{mg} / \mathrm{dl}), \mathrm{DR}(56.60 \pm 7.66$

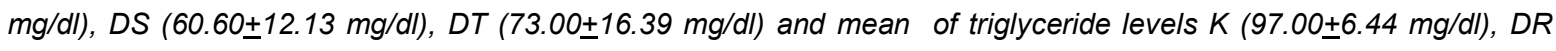
$(27.80 \pm 11.90 \mathrm{mg} / \mathrm{dl}), \mathrm{DS}(29.20 \pm 16.02 \mathrm{mg} / \mathrm{dl}), \mathrm{DT}(36.00 \pm 15.08 \mathrm{mg} / \mathrm{dl})$. One-way ANOVA dan Post-hoc tests analysis showed significant differences of total cholesterol and triglyceride levels among control and treatment groups $(p<0.05)$ but not between the treatment group ( $p>0.05)$. The conclusion of this study is significant differences in total cholesterol and triglycerides between control and treatment groups, but the differences of doses don't give significant differences. Keywords: coffee, caffeine, cholesterol, triglyceride
\end{abstract}


Affiliasi penulis: 1. Prodi Profesi Dokter FK Unand (Fakultas Kedokteran Universitas Andalas Padang), 2. Bagian Biokimia FK Unand, 3. Bagian Patologi Klinik FK Unand

Korespondensi: Millah Fithriyah Zindany, Email:

millah_fz@yahoo.com, Telp: 081374975946

\section{PENDAHULUAN}

Kopi merupakan salah satu minuman yang paling banyak dikonsumsi di dunia. Di daerah Asia, kebiasaan minum kopi menunjukkan peningkatan selama lebih dari dua puluh tahun. Kebiasaan mengonsumsi kopi sering dikaitkan dengan kelainan pada kesehatan dan berbagai macam penyakit. Banyak penelitian melaporkan bahwa kopi dapat meningkatkan kolesterol darah, homosistein serum dan tekanan darah yang dapat menjadi faktor risiko meningkatnya penyakit jantung koroner. ${ }^{1-3}$

Kandungan kopi terdiri dari lebih seribu molekul zat yang berbeda, termasuk senyawa fenolik, vitamin, mineral dan alkaloid. Kafein, cafestol, kahweol dan chlorogenic acid berhubungan dengan metabolisme lipid dan secara teoritis dapat mempengaruhi profil lipid serum. ${ }^{4}$

Para ahli terus mencari pengaruh kopi terhadap kesehatan. Beberapa penelitian menyimpulkan adanya hubungan positif antara konsumsi kopi dengan peningkatan lipid serum. Salah satu penelitian yang dilakukan pada 17 orang yang sehat kemudian diberikan diet 6 cangkir kopi selama 4 minggu menunjukkan peningkatan kadar kolesterol total (TC) sebesar $22 \mathrm{mg} / \mathrm{dl} .{ }^{5}$ Penelitian lain menunjukkan hasil serupa, terjadi peningkatan kadar kolesterol total pada kelompok dengan konsumsi 3 cangkir kopi atau lebih per hari dan peningkatan trigliserida (TG) dengan konsumsi 5 cangkir kopi atau lebih per hari. ${ }^{6}$ Cross sectional study yang dilakukan terhadap 77 orang lakilaki usia 30-55 tahun menunjukkan peningkatan TC dan TG plasma namun tidak pada HDL plasma dengan diet 2 cangkir kopi/ hari. $^{7}$

Penelitian lain menunjukkan hasil berbeda, konsumsi kafein terhadap tikus jantan tidak memberikan efek pada lipid serum. ${ }^{8}$ Selanjutnya beberapa peneliti mendapatkan hasil terjadi penurunan TC dan TG pada kelompok dengan diet kafein selama 4 minggu pada mencit. ${ }^{9}$
Ada lebih dari 2.000 zat telah diisolasi dari kopi. Sebanyak 23\% melanoidin dalam kopi yang merupakan zat warna dan memberi warna coklat pada biji kopi. Komponen alkaloid yang sering menjadi pusat perhatian untuk diteliti adalah kafein yang membentuk 1,3 - 2,4\% dari keseluruhan berat biji kopi, diikuti oleh alkaloid purin lainnya seperti theobromin, theophylline, dan trigonelline. ${ }^{10}$

Kafein merupakan zat psikoaktif yang paling banyak dikonsumsi setiap harinya oleh masyarakat dunia karena banyak ditemukan dalam bahan makanan serta obat-obatan. Zat ini bahkan terdapat secara alamiah pada lebih dari 63 spesies tanaman. Obat-obatan yang mengandung kafein tersebut kebanyakan dijual bebas dan belum ada regulasi dalam pengontrolan penjualannya. Diperkirakan bahwa konsumsi kafein harian di Amerika Serikat mencapai $206 \mathrm{mg}$ per orang. ${ }^{10,11}$

Senyawa kafestol dan kahweol adalah alkohol diterpen pentasiklik. Kafestol adalah konstituen utama dari reaksi penyabunan minyak kopi yaitu sekitar 0,2 $0,6 \%$ dari berat kopi. Zat ini bersifat anti kanker dan hepatoprotektif. Hasil berbeda didapatkan bila zat ini dikonsumsi dalam jumlah tinggi. Hasil penelitian menunjukkan hubungan positif konsumsi kafestol dan kahweol dengan peningkatan serum kolesterol, low density lipoprotein (LPL) plasma dan peningkatan homosistein yang mungkin secara tidak langsung meningkatkan risiko penyakit kardivaskuler. ${ }^{12}$

Pada penelitian ini, telah dilakukan pengujian dari pengaruh kopi terhadap kadar kolesterol total dan trigliserida tikus.

\section{METODE}

Jenis penelitian ini adalah eksperimental dengan rancangan post test only control group design dengan 1 kelompok kontrol dan 3 kelompok perlakuan yang menggunakan hewan coba sebagai subjek penelitian. Populasi dalam penelitian ini adalah tikus putih (Rattus novergiccus) jantan strain Wistar dengan periode penelitian 23 Maret sampai 19 April 2014. Sampel dari penelitian ini adalah tikus putih yang dipilih secara acak, berumur 2-3 bulan dengan berat badan sekitar 150-200 gram. Kriteria inklusi adalah 
tikus putih jantan galur Wistar (Rattus norvegiccus), umur 2-3 bulan, berat badan 150-200 g. Kriteria eksklusinya adalah sampel dianggap drop out apabila selama penelitian dilaksanakan tikusputih jantan sakit dan mati.

Sampel penelitian ini adalah 24 ekor tikus putih jantan (Rattus novergiccus) yang dibagi menjadi 4 kelompok yaitu kelompok kontrol $(\mathrm{K})$, perlakuan 1 (DR), perlakuan 2 (DS), dan perlakuan 3 (DT). K hanya diberi diet standar tanpa kopi, DR diberikan diet kopi dosis rendah setara 3 cangkir kopi $(0,39 \mathrm{mg} / 3$ $\mathrm{ml}$ ), DS diberikan diet kopi dosis sedang setara 6 cangkir kopi $(0,78 \mathrm{mg} / 3 \mathrm{ml})$, DT diberikan diet kopi dosis tinggi setara 10 cangkir kopi (1,3 mg/ 3ml) selama 4 minggu (28 hari). Pengukuran kadar kolesterol dan trigliserida menggunakan spektofotometer.

Analisis data terhadap perubahan kadar kolesterol dan trigliserida dilakukan melalui uji hipotesis komparatif dan korelatif, yaitu uji One-Way ANOVA.

\section{HASIL}

Penelitian yang telah dilakukan di laboratorium Hewan FMIPA Jurusan Farmasi Universitas Andalas Padang untuk pemeliharaan hewan percobaan dan Laboratorium Sejawat, Padang untuk pemeriksaan kadar kolesterol dan trigliserida pada tikus .Tikus terdiri dari 24 ekor dan dibagi atas 4 kelompok dengan prosedur 6 ekor tikus sebagai kelompok kontrol yang diberi diet standar ad libitum, 6 ekor tikus sebagai kelompok perlakuan 1 yang diberi diet kopi dosis rendah, 6 ekor tikus sebagai kelompok perlakuan 2 yang diberi diet kopi dosis sedang, dan 6 ekor tikus sebagai kelompok perlakuan 3 yang diberi diet kopi dosis tinggi. Dalam pelaksanaan penelitian tidak terdapat tikus yang mati, tetapi salah satu sampel darah mengalami hemolisis setelah disentrifugasi sehingga dikeluarkan dari kelompok dan untuk menyeragamkan data, serum yang diperiksa dipilih sebanyak 5 sampel setiap kelompok secara acak.
Tabel 1. Nilai rerata kadar kolesterol $(\mathrm{mg} / \mathrm{dl})$

\begin{tabular}{lclc}
\hline \multicolumn{1}{c}{ Kelompok } & n & Rerata \pm SD & \multicolumn{1}{c}{ p } \\
\hline Kontrol & 5 & $35,80 \pm 10,84$ & \\
Perlakuan 1 (DR) & 5 & $56,60 \pm 7,66$ & $0,023^{*}$ \\
Perlakuan 2 (DS) & 5 & $60,60 \pm 12,13$ & $0,006^{*}$ \\
Perlakuan 3 (DT) & 5 & $73,00 \pm 16,39$ & $0,000^{*}$
\end{tabular}

Keterangan: $\mathrm{p}$ merupakan hasil uji Post-hoc terhadap kelompok kontrol; ${ }^{*}=$ terdapat perbedaan yang bermakna $(p<0,05)$

Tabel 1 menunjukkan nilai rerata kolesterol ketiga kelompok perlakuan mengalami peningkatan sesuai dengan dosis pemberian kopi bila dibandingkan dengan kelompok kontrol. Peningkatan kadar kolesterol total serum paling tinggi terjadi pada kelompok 3, dilanjutkan kelompok 2, dan kelompok 1.

Tabel 2. Hasil uji Post-hoc rerata kadar kolesterol total pada kelompok perlakuan

\begin{tabular}{cccc}
\hline Kelompok & DR & DS & DT \\
\hline Perlakuan 1 (DR) & - & 1,000 & 0,103 \\
Perlakuan 2 (DS) & 1,000 & - & 0,369 \\
Perlakuan 3 (DT) & 0,103 & 0,369 & - \\
\hline
\end{tabular}

Syarat uji statistik parametrik dengan one way ANOVA ialah sebaran data harus normal dan varian data harus sama. Untuk mengetahui apakah distribusi data normal maka dilakukan uji Kolmogorov-Smirnov dan didapatkan nilai $p=0,903$. Karena nilai $p>0,05$, maka dapat diambil kesimpulan bahwa distribusi data adalah normal.

Uji homogenitas varian dilakukan pada hasil pengukuran kolesterol keempat kelompok tikus. Berdasarkan uji tersebut, maka didapatkan nilai significancy $p=0,479(p>0,05)$, yang berarti tidak ada perbedaan varian antara kelompok data yang dibandingkan.

Hasil uji One-Way ANOVA menunjukkan terdapat perbedaan bermakna kadar kolesterol di dalam kelompok, dengan $p=0,000 \quad(p<0,05)$. Hasil analisis post-hoc memperlihatkan terdapat perbedaan yang signifikan rerata kolesterol total antara kelompok 
perlakuan dengan kelompok kontrol. Kelompok DR, DS, DT memiliki $p<0,05$ bila dibandingkan dengan kelompok kontrol. Tabel 2 menunjukkan tidak terdapat perbedaan bermakna kadar kolesterol darah antar kelompok perlakuan $(p>0,05)$.

Tabel 3. Nilai rerata kadar trigliserida(mg/dl)

\begin{tabular}{lclc}
\hline \multicolumn{1}{c}{ Kelompok } & n & Rerata \pm SD & p \\
\hline Kontrol & 5 & $97,00 \pm 6,44$ & \\
Perlakuan 1 (DR) & 5 & $27,80 \pm 11,90$ & $0,000^{*}$ \\
Perlakuan 2 (DS) & 5 & $29,20 \pm 16,02$ & $0,000^{*}$ \\
Perlakuan 3 (DT) & 5 & $36,00 \pm 15,08$ & $0,000^{*}$
\end{tabular}

Keterangan: $p$ merupakan hasil uji Post-hoc terhadap kelompok kontrol; ${ }^{*}=$ perbedaan yang bermakna $(p<0,05)$

Data pada Tabel 3 menunjukkan nilai rerata trigliserida pada kelompok kontrol paling tinggi diantara semua kelompok. Ketiga kelompok perlakuan mengalami penurunan kadar trigliserida jika Dibandingkan dengan kelompok kontrol. Penurunan paling besar pada kelompok perlakuan 1 , selanjutnya kelompok perlakuan 2 , dan penurunan paling sedikit terjadi pada kelompok perlakuan 3 .

Uji Kolmogorov-Smirnov terhadap kadar trigliserida mendapatkan nilai $p=0,107(p>0,05)$ dan uji homogenitas varian menunjukan $p=0,357 \quad(p>0,05)$, kemudian dilakukan uji one-way ANOVA dan memperoleh nilai $p=0,000 \quad(p<0,05)$. Hasil tersebut menunjukkan terdapat perbedaan bermakna kadar kolesterol dalam kelompok. Uji Post-Hoc menunjukkan hasil terdapat perbedaan yang bermakna antara kelompok kontrol dengan kelompok perlakuan 1 $(p=0,000)$, kelompok kontrol dengan kelompok perlakuan $2(p=0,000)$, dan kelompok kontrol dengan kelompok perlakuan $3(p=0,000)$. Hasil uji nilai rerata trigliserida serum antara kelompok kontrol dengan kelompok yang diberi diet kopi dosis rendah menunjukkan perbedaan yang bermakna, begitu juga dengan kelompok kontrol dengan kelompok yang diberi diet kopi dosis sedang, dan kelompok kontrol dengan kelompok yang diberi diet kopi dosis tinggi namun tidak terdapat perbedaan bermakna antar kelompok perlakuan $(p>0,05)$, dengan hasil sebagai berikut yang terlihat dalam Tabel 4 .
Tabel 4. Hasil uji post-hoc rerata kadar trigliserida pada kelompok perlakuan

\begin{tabular}{cccc}
\hline Kelompok & DR & DS & DT \\
\hline Perlakuan 1 (DR) & - & 1,000 & 1,000 \\
Perlakuan 2 (DS) & 1,000 & - & 1,000 \\
Perlakuan 3 (DT) & 1,000 & 1,000 & - \\
\hline
\end{tabular}

\section{PEMBAHASAN}

Kadar kolesterol total tikus pada kelompok perlakuan yang diberi diet kopi dosis rendah, sedang, dan tinggi lebih tinggi dibandingkan dengan rerata kadar kolesterol total kelompok kontrol. Kelompok yang diberi diet kopi dosis rendah memiliki rerata kadar kolesterol total 56,60 mg/dl, kelompok diet kopi dosis sedang memiliki rerata kadar kolesterol 60,60 $\mathrm{mg} / \mathrm{dl}$, dan kelompok diet kopi dosis tinggi 73,00 mg/dl. Perbedaan yang bermakna didapatkan setelah dilakukan uji analisis antara kelompok kontrol dengan ketiga kelompok perlakuan $(p<0,05)$.

Peningkatan kadar kolesterol total pada kelompok perlakuan dapat terjadi karena pengaruh pemberian kopi yang dapat menginduksi pelepasan free fatty acid (FFA). FFA termasuk salah satu prekursor utama asetil KoA yang akan menjadi prekursor biosintesis kolesterol. Beberapa studi yang dilakukan terhadap manusia menunjukkan terjadinya peningkatan FFA sebagai akibat tingginya lipolisis karena konsumsi kopi. ${ }^{6,13,14}$ Studi metaanalisis yang dilakukan menyatakan pemberian suplemen diterpene dapat menyebabkan terjadinya peningkatan kadar kolesterol serum sekitar $0,13 \mathrm{mmol}(5,0 \mathrm{mg} / \mathrm{dl})$. Diterpen (kafestol dan kahweol) terkandung dalam fraksi lipid pada biji kopi sebanyak $10-15 \% .{ }^{15}$

Peningkatan kadar kolesterol total juga didapatkan pada penelitian yang memberikan diet 1,5 $\mathrm{ml} / 100 \mathrm{~g}$ BB tikus selama 6 minggu. Kopi yang diberikan dalam dosis tinggi dimana $10 \mathrm{~g}$ bubuk kopi dilarutkan dalam $10 \mathrm{ml}$ air, artinya dalam $1,5 \mathrm{ml}$ larutan kopi terkandung $1,5 \mathrm{~g}$ bubuk kopi. Jumlah kopi tersebut setara dengan 10 - 11 cangkir kopi bila dikonsumsi oleh lelaki dengan BB $70 \mathrm{~kg}$. Hasil penelitian tersebut menunjukkan peningkatan yang bermakna pada kadar kolesterol total antara kelompok perlakuan dengan kelompok kontrol $(p<0,05) .{ }^{16}$ 
Hasil yang didapat pada penelitian ini berbeda dengan hasil penelitian terhadap tikus Wistar yang diberi diet kopi dosis tinggi yang setara dengan 12 cangkir kopi selama 4 minggu yang tidak menunjukkan perbedaan bermakna pada kadar kolesterol total dan trigliserida serum dibandingkan kelompok kontrol $(p>0,05)$. Perbedaan bermakna kadar kolesterol total serum terdapat dengan pemberian kopi pada kelompok yang diberikan diet hiperkolesterol dibandingkan kelompok kontrol $(p<0,01)$ dan juga bila dibandingkan dengan kelompok yang diberi diet kopi saja $(p<0,01) .{ }^{8}$ Hal ini dapat terjadi karena estimasi kopi yang terkandung dalam satu cangkir berbeda dan jenis kopi yang diberikan terhadap hewan coba berbeda.

Uji analisis yang dilakukan pada penelitian tidak menunjukkan perbedaan bermakna kadar kolesterol total antar kelompok perlakuan dengan $p>0,05$. Hal ini menunjukkan bahwa pemberian diet kopi dapat meningkatkan kadar kolesterol secara signifikan namun tidak terdapat perbedaan bermakna dengan pemberian dosis yang berbeda secara statistik. Hasil serupa juga didapatkan pada penelitian dengan pemberian diet rendah kopi $(15 \mathrm{~g} / 100 \mathrm{ml})$ dan diet tinggi kopi $(30 \mathrm{~g} / 100 \mathrm{ml})$ selama 7 minggu yang menunjukkan peningkatan kadar TC yang signifikan antara masing-masing kelompok perlakuan dibandingkan dengan kelompok kontrol $(p<0,05)$. Rerata kadar TC antara kelompok diet tinggi kopi lebih tinggi dibandingkan diet rendah kopi namun tidak terdapat perbedaan bermakna dalam uji statistik $(p>0,05){ }^{17}$

Hasil penelitian mengenai efek kopi terhadap trigliserida tikus dapat dilihat pada Tabel 3 dan 4 . Rerata trigliserida pada ketiga kelompok perlakuan mengalami penurunan bila dibandingkan dengan rerata trigliserida pada kelompok kontrol. Nilai rerata trigliserida pada kelompok kontrol pada penelitian ini adalah $97 \mathrm{mg} / \mathrm{dl}$. Perbedaan bermakna didapatkan setelah dilakukan uji analisis antara kelompok perlakuan 1, 2, dan 3 dengan kelompok kontrol $(p<0,05)$. Penurunan kadar trigliserida ini dapat terjadi karena pengaruh kafein yang terdapat di dalam kopi dapat meningkatkan kadar asam lemak akibat pengaruh positif dari hormon sensitif lipase. ${ }^{4}$
Penelitian eksperimental memperlihatkan terjadinya penurunan trigliserida pada serum tikus yang diberi diet kopi $0,12 \mathrm{~g} / 100 \mathrm{~g}$ berat badan tikus setiap hari selama 4 minggu dibandingkan dengan kelompok kontrol. Penurunan yang terjadi sebesar $27,75 \mathrm{mg} / \mathrm{dl}$ tetapi tidak didapatkan perbedaan yang signifikan setelah diuji secara statistik $(p>0,05) .{ }^{18}$ Penelitian pada manusia yang dilakukan dengan sampel 11 orang laki-laki usia 21 - 31 tahun menunjukkan penurunan TG plasma setelah diberi diet 3 cangkir kopi $(1$ cangkir $=150 \mathrm{ml}$ ) selama seminggu namun juga tidak ditemukan perbedaan yang signifikan setelah dilakukan uji analisis $(p>0,05) .{ }^{19}$

Rerata kadar trigliserida pada kelompok perlakuan dengan diet kopi dosis rendah adalah 27,80 $\mathrm{mg} / \mathrm{dl}$. Kelompok perlakuan dengan diet kopi dosis sedang memiliki nilai rerata trigliserida $29,20 \mathrm{mg} / \mathrm{dl}$, dan rerata kadar trigliserida pada kelompok dengan diet kopi dosis tinggi yaitu $36,00 \mathrm{mg} / \mathrm{dl}$. Ketiga kelompok memiliki perbedaan yang bermakna dengan $p<0,05$ bila dibandingkan dengan kelompok kontrol tetapi tidak terdapat perbedaan bermakna setelah dilakukan uji analisis antara ketiga kelompok perlakuan tersebut. Hal ini menunjukkan bahwa pemberian kopi terhadap tikus secara signifikan dapat menurunkan kadar TG serum tetapi perbedaan dosis yang diberikan tidak menunjukkan perbedaan yang bermakna.

\section{SIMPULAN}

Pemberian kopi berpengaruh terhadap kadar kolesterol total serum pada tikus Wistar normal dan bermakna secara statistik. Perbedaan dosis kopi pada kelompok perlakuan mempengaruhi peningkatan kadar kolesterol total serum tetapi tidak bermakna secara statistik. Pemberian kopi berpengaruh terhadap kadar trigliserida serum pada tikus Wistar normal dan bermakna secara statistik tetapi perbedaan dosis pada kelompok perlakuan tidak menunjukkan penurunan yang bermakna secara statistik.

\section{UCAPAN TERIMA KASIH}

Terima kasih kepada semua pihak yang telah banyak memberikan arahan dan masukan dalam penelitian ini. 


\section{DAFTAR PUSTAKA}

1. Choi EY, Jang JY, Cho YO. Coffee intake can promote activity of antioxidant enzymes with increasing MDA level and decreasing HDLcholesterol in physically trained rats. Nutr Res Pract. 2010;4(4):283-9.

2. Freedman ND, Park $Y$, Abnet CC, Hollenbeck AR, Sinha R. Association of coffee drinking with total and cause specific mortality. N Eng J Med. 2012; 366(20):1891 - 904.

3. Naidoo N, Chen C, Rebello SA, Speer, K, Tai ES, Lee $\mathrm{J}$, et al. Cholesterol-raising diterpenes in types of coffee commonly consumed in Singapore, Indonesia, and India and association with blood lipids. Nutrition Journal. 2011;10:48.

4. Grzegorzewska AE, Michalska MM, Wobszal P. Does ingestion of regular coffee influence serum lipid profile in dialysis patients? Advances in peritoneal dialysis. 2009;25:181-6.

5. Arnesen E, FØrde OH, Thelle DS. Coffee and serum cholesterol. BMJ. 1984;288:1960.

6. Green MS, Jucha E. Association of serum lipid with coffee, tea, and egg consumption in free-living subjects. Journal of Epidemiology and Community Health. 1986;40:324 - 9.

7. William PT, Wood PD, Vranizan KM, Albers JJ, Garay SC, Tylor CB. Coffee intake and elevated cholesterol and apolipoprotein B levels in men. JAMA 2010 (diunduh 15 Januari 2013). Tersedia dari: URL: HYPERLINK http://www.ncbi.nlm.nih. gov/pmc/articles/PMC2864577/

8. Rakicioglu N, Pekcan G, dan Cevik A. The effect of coffee and caffeine consumption on serum lipids in rats. IJNFS.1998; 49(6):p44(1).

9. Sugiura C, Nishimatsu A, Moriyama T, Ozasa S, Kawada T, Sayama K. Catechins and caffeine inhibit fat accumulation in mice through the improvement of hepatic lipid metabolism. Journal of Obesity. 2012;1 - 10.

10. Echeverry D, Montes FR, Cabrera M, Galán A, Prieto A. Caffeine's vacular mechanism of action.
International Journal of Vascular Medicine. 2010; $1-10$.

11. de Man JM. Principles of food chemistry. Dalam: Padmawinata K, Sutomo T, editor (penyunting). Kimia makanan. Edisi ke-2. Bandung: Penerbit ITB; 1997.

12. Farah A. Coffee: emerging health and disease prevention First edition. Blackqwell Publishing Ltd; 2012.

13. Greenberg JA, Owen DR, Geliebter A. Decaffeinated coffee and glucose metabolism in young men. Diabetes Care. 2010;33(2).

14. Marks DB, Marks AD, Smith CM. Basic medical biochemistry: a clinical approach. Dalam: Suyono J, Sadikin V, Mandera LI, editor penterjemah. Biokimia kedokteran dasar: sebuah pendekatan klinis. Jakarta: EGC; 2000.

15. Urgert R, Katan MB. The cholesterol-raising factor from coffee beans. J R Soc Med. 1996;89:618 23.

16. Rezq AA, Fathy NM. Effect of regular drinking of boiled, filtered or Turkish coffee and its impact on some biochemical parameters relevant to atherogenicity and the function of the kidney and the liver in rat model. European Journal of Biological Sciences. 2010;2(3):46 - 54.

17. Hanaa, El-Fattah MA. Nutritional interaction effect of zinc and coffee on serum lipid profile and copper in rats. The Egyptian Journal of Hospital Medcine. 2008;33:492 - 502.

18. Choi EY, Park SY, Cho YO. Freeze-dried instant coffee can promote the activities of antioxidant enzymes and induce weight loss but also aggravate the plasma cholesterol profile in rats. Elsevier. 2011; 1 - 4.

19. Yukawa GS, Mune $M$, Otani $H$, Tone $Y$, Liang XM, Iwanashi $\mathrm{H}$, et al. Effects of coffee consumption on oxidative susceptibility of low-density lipoproteins and serum lipid in humans. Biochemistry (Moscow). 2004; 69 (1): $70-4$. 